\title{
Extended Red Blood Cell Phenotype Matching Is Dependent on Ethnicity and Specificity of RBC Alloantibodies
}

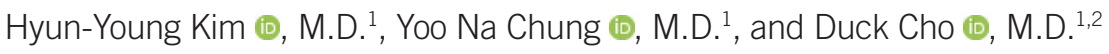 \\ ${ }^{1}$ Department of Laboratory Medicine and Genetics, Samsung Medical Center, Sungkyunkwan University School of Medicine, Seoul, Korea; ${ }^{2}$ Department of \\ Health Sciences and Technology, Samsung Advanced Institute for Health Sciences and Technology, Sungkyunkwan University, Seoul, Korea
}

To the Editor,

We would like to thank Balbuena-Merle and colleagues [1] for their interest in our study of red blood cell (RBC) alloimmunization in Korean patients with myelodysplastic syndrome (MDS) and liver cirrhosis (LC) [2]. There is a high prevalence of sickle cell disease (SCD) in Africa, the Middle East, India, parts of the Mediterranean, and Puerto Rico, and high rates of RBC alloimmunization in SCD patients have been reported in these regions [3]. In contrast, SCD is extremely rare in Korea, and alloimmunization in SCD patients has never been documented. The frequencies of $\mathrm{C}, \mathrm{C}, \mathrm{E}, \mathrm{e}, \mathrm{Fy} \mathrm{y}^{\mathrm{a}}, \mathrm{Jk}^{\mathrm{a}}, \mathrm{M}$, and $\mathrm{K}$ antigens differ across races. The $\mathrm{K}$ antigen is particularly important as it has high immunogenicity; however, the frequencies of the $\mathrm{K}$ antigen and the anti-K alloantibody are extremely low in the Korean and other South East Asian (i.e., Chinese and Japanese) populations, unlike in European and Caucasian populations [4, 5].

With respect to the transfusion policies, the study by Balbuena-Merle, et al. [1] from Puerto Rico was different from our study in Korea because of the differences in disease prevalence and alloantibody formation. While $91 \%$ of pediatric SCD patients $S C D$ received $\mathrm{RBCs}$ matched for at least $\mathrm{ABO}, \mathrm{Rh}$, and $\mathrm{K}$ blood groups (limited RBC matching), none of the patients in our study received RBCs matched for groups other than $\mathrm{ABO}$ and RhD (Table 1). However, the overall alloimmunization rate (15.4\% [8/52 patients] vs 6.3\% [20/317 patients]) was much lower in our study despite the similar amount of transfused RBC units; this was considered to be due to the higher ethnic homogeneity of Koreans than that of Puerto Ricans. Although Balbuena-Merle, et al. [1] described Puerto Ricans as a genetically homogeneous group, their population comprises Caucasians (74.7\%), people of African descent (15.3\%), and other populations according to the 2013-2017 American Community Survey [6]. We additionally calculated the prevalence of alloantibody formation per transfusion events. After transfusion of 5,886 RBC units, the formation of 29 alloantibodies was recorded, and the prevalence of alloantibody formation per transfusion event was 0.49 alloantibodies per 100 units. Among the disease groups, the prevalence of alloantibody formation per transfusion event was the highest in the LC group (1.13 per 100 units), followed by the MDS group (0.22 per 100 units), and the prevalence among Puerto Rican patients was 3 per 100 units.

In our study, the most common alloantibody was that against
Received: September 26, 2019

Revision received: October 10, 2019

Accepted: October 14, 2019

Corresponding author: Duck Cho, M.D., Ph.D.

Department of Laboratory Medicine \& Genetics, Samsung Medical Center, Sungkyunkwan University School of Medicine, 81 Irwon-ro, Gangnam-gu, Seoul 06351, Korea

Tel: +82-2-3410-2403, Fax: +82-2-3410-2719, E-mail: duck.cho@skku.edu

\section{(c) (i) (2)}

\section{(c) Korean Society for Laboratory Medicine}

This is an Open Access article distributed under the terms of the Creative Commons Attribution Non-Commercial License (http://creativecommons.org/licenses/by-nc/4.0) which permits unrestricted non-commercial use, distribution, and reproduction in any medium, provided the original work is properly cited. 
Kim HY, et al.

Extended RBC phenotype matching

Table 1. Comparison of the studies by Kim, et al. [2] and Balbuena-Merle, et al. [1] for RBC antigen prevalence and alloimmunization rate

\begin{tabular}{|c|c|c|}
\hline Study & Kim, et al. [2] & Balbuena-Merle, et al. [1] \\
\hline Study Population & Adult LC and MDS patients & Pediatric SCD population \\
\hline Ethnicity & Korean & Puerto Rican \\
\hline RBC phenotype matching & $\mathrm{ABO} / \mathrm{D}$ matched & $\begin{array}{l}\text { ABO/D matched and other phenotype matched (limited- and } / 0 \\
\text { extended matched) }\end{array}$ \\
\hline RBC alloimmunization rate & $6.3 \%$ & $15.4 \%$ \\
\hline Prevalence of alloantibody formation per transfusion events & 0.49 per 100 units & 3 per 100 units \\
\hline \multicolumn{3}{|l|}{ Prevalence of RBC antigens* } \\
\hline $\mathrm{C}$ & $85 \%$ & $67 \%$ \\
\hline $\mathrm{E}$ & $51 \%$ & $25 \%$ \\
\hline$c$ & $59 \%$ & $86 \%$ \\
\hline e & $90 \%$ & $98 \%$ \\
\hline M & $76 \%$ & $69 \%$ \\
\hline K & $0 \%$ & $6 \%$ \\
\hline $\mathrm{Fy}^{\mathrm{a}}$ & $99 \%$ & $46 \%$ \\
\hline$J k^{\mathrm{a}}$ & $67 \%$ & $88 \%$ \\
\hline \multicolumn{3}{|l|}{ Identified RBC alloantibodies (N) } \\
\hline Anti-E & $13(45 \%)$ & $1(11 \%)$ \\
\hline Anti-c & $5(17 \%)$ & 0 \\
\hline Anti-e & $3(10 \%)$ & 0 \\
\hline Anti-C & $2(7 \%)$ & 0 \\
\hline Anti-M & 0 & $4(44 \%)$ \\
\hline Anti-Fy ${ }^{\mathrm{a}}$ & 0 & $2(22 \%)$ \\
\hline Anti-Fy ${ }^{b}$ & $2(7 \%)$ & 0 \\
\hline Anti-Jk ${ }^{\mathrm{a}}$ & $2(7 \%)$ & $1(11 \%)$ \\
\hline Anti-K & 0 & $1(11 \%)$ \\
\hline
\end{tabular}

*Data on the prevalence of RBC antigens in Koreans were derived from references [5] and [10].

Abbreviations: LC, liver cirrhosis; MDS, myelodysplastic syndrome; SCD, sickle cell disease; RBC, red blood cell.

the Rh system, found in $80 \%$ of alloimmunized patients. However, Balbuena-Merle, et al. [1] reported only one patient with an Rh alloantibody (anti-E), and as expected, this must be the effect of limited or extended RBC phenotype matching. Several studies have reported reduced alloimmunization rates after limited RBC antigen (ABO, Rh, and Kell systems)-matched transfusion $[7,8]$.

Although RBC alloimmunization rates in Korea are low, these values are set to change in the near future owing to increased rates of immigration and interethnic marriages [9]. Both these factors could lead to changes in the RBC antigen expression profile and thereby the alloimmunization rate and alloantibody distribution of the population [5]. Therefore, continuous monitoring of RBC alloimmunization for various conditions is needed.
When the specificity of RBC alloantibodies in Koreans changes significantly, the introduction of extended RBC antigen matching should be considered in Korea.

\section{Conflicts of Interest}

None declared.

\section{ORCID}

Hyun-Young Kim https://orcid.org/0000-0003-0553-7096

Yoo Na Chung

Duck Cho 


\section{REFERENCES}

1. Balbuena-Merle RI, Nazario-Delgado CM, Rosario-Rosado RV, MillánTapia D, Climent-Peris C. Red blood cell alloimmunization in the pediatric sickle cell disease population of the Puerto Rico: an observational study. Ann Lab Med 2020;40:187-9.

2. Kim HY, Cho EJ, Chun S, Kim KH, Cho D. Red blood cell alloimmunization in Korean patients with myelodysplastic syndrome and liver cirrhosis. Ann Lab Med 2019;39:218-22.

3. Samarah F, Srour MA, Yaseen D, Dumaidi K. Frequency of red blood cell alloimmunization in patients with sickle cell disease in Palestine. Adv Hematol 2018;2018:5356245.

4. Cheng CK, Lee CK, Lin CK. Clinically significant red blood cell antibodies in chronically transfused patients: a survey of Chinese thalassemia major patients and literature review. Transfusion 2012;52:2220-4.

5. Shin KH, Lee HJ, Kim HH, Hong YJ, Park KU, Kim MJ, et al. Frequency of red blood cell antigens according to parent ethnicity in Korea using molecular typing. Ann Lab Med 2018;38:599-603.

6. U.S. Census Bureau. American Community Survey and Puerto Rico Community Survey, 2013-2017 American Community Survey 5-Year Estimates, Table DP05, generated using American FactFinder. http:// factfinder.census.gov (Updated on Sep 2019).

7. Ameen R, Al Shemmari S, Al-Bashir A. Red blood cell alloimmunization among sickle cell Kuwaiti Arab patients who received red blood cell transfusion. Transfusion 2009;49:1649-54.

8. Fasano RM, Meyer EK, Branscomb J, White MS, Gibson RW, Eckman JR. Impact of red blood cell antigen matching on alloimmunization and transfusion complications in patients with sickle cell disease: a systematic review. Transfus Med Rev 2019;33:12-23.

9. Statistics Korea. International migration statistics in 2017: marriage and divorce statistics in 2018. http://kostat.go.kr/portal/eng/pressReleases/8/1/index.board (Updated on Oct 2019).

10. Han KS, Park KU, et al. Transfusion Medicine 4th ed.: Korea Medical Book Publishing Company, 2014:212-23. 